\title{
Curriculum System Reform for Management Majors Based on the Paradigm of "Sydney Accord"
}

\author{
$\mathbf{L i ~ L i}^{*}$ \\ Zhejiang Business College, Hangzhou 310053, China
}

*Corresponding author: Li Li, $20179190 @ q q . c o m$

\begin{abstract}
The curriculum system is the guiding ideology of educational activities as well as the concretization and support of training objectives. It stipulates the planning scheme for the implementation of training objectives. The curriculum system is mainly composed of specific curriculum view, curriculum goal, curriculum content, curriculum structure, and curriculum activity mode, in which professional talent training goal, talent training specification, and systematic curriculum play important roles. This article relies on the first batch of research projects on teaching under the "13th Five-Year Plan" for higher education by Zhejiang Provincial Department of Education in 2018. It sorts out and summarizes the practical experience of teaching reform involved in the project, so as to further explore scientific and effective ways of professional teaching reform.
\end{abstract}

Keywords: TAC/TAC-AD (Sydney Accord); Curriculum system

Publication date: November 2021; Online publication: November 30, 2021

\section{Introduction}

At present, higher vocational colleges are pursuing scale expansion and entering the transformation stage of emphasizing on connotation as well as improving quality. The important starting point of vocational education development in terms of connotation is professional construction, and one of the core contents of professional construction is the advancement of the professional curriculum system with the times and practice. Its scientificity and rationality directly affect the quality of talent training. Learning from advanced and mature international experiences while considering the actual situation in China, a strategy to improve the quality of higher vocational colleges is by constructing a more scientific, practical, and advanced professional curriculum system.

\section{Analysis of problems before reform}

As the implementation carrier of professional top-level design and talent training standard construction, the current situation of professional curriculum system construction in China is discussed below.

\subsection{Clear orientation of talent training, but lacking practicability and systematicness in the curriculum system}

With the rapid development of regional economy in Zhejiang Province and the urgent need for talents in the industry, the business management specialty of Zhejiang Business College has carried out in-depth industry-education integration projects with digital enterprises and brand jewelry enterprises. On the basis of cooperation with industries and enterprises, it is necessary to conduct research on the demand for management talents in relevant industries. The survey results revealed two main ways in selecting management talents by enterprises: the first is through social recruitment, accounting for about $40.74 \%$; the 
second is through school recruitment, accounting for about $38.63 \%$; the ratio of the two is very close. From the perspective of employee loyalty and sustainable development, enterprises prefer to recruit fresh graduates from schools.

However, when enterprises recruit fresh graduates, they face a prominent problem, whereby the knowledge of business enterprise management students and their skills are lacking, with an obvious gap between the knowledge learned and the actual situation of industries as well as enterprises. The root of this problem is the lack of systematicness in the current curriculum system of business administration. Due the constraints of traditional discipline thinking, only a small number of industry-related courses are included on the basis of removing some courses from the industrial and commercial enterprise management discipline, failing to form a closely related post, perfect structure, and progressive curriculum system as well as in reflecting the progressive training of ability and comprehensive quality in the specification of talent training; thus, the needs of the industry and enterprises for management talents are not met.

\subsection{The development of curriculum standards has begun to take shape, but the formulation of standards lacks scientificity and ecology}

Relying on construction projects such as school level key majors and modern apprenticeship system, the enterprise management specialty has completed the formulation of curriculum standards to guide teaching practice. However, due to the lack of detailed decomposition of professional training objectives, which is reflected in the lack of specific indicators of talent training specifications, the construction quality of these curriculum standards is uneven. First, there are differences in the concept of standard development among teachers, resulting in the lack of standardization and preciseness in content structure and details, language expression, and so on. Second, due to the lack of scientific and systematic planning as well as guidance at the professional level, their subjective will in curriculum content setting is too strong, and teachers fail to understand the significance of curriculum setting from the top-level design of professional talent training, resulting in cross content, high repetition rate, separation, and low cohesion between courses. Therefore, many courses are unable to carry out targeted teaching activities according to the specific problems of students in industries and enterprises.

\section{The important role of the TAC/TAC-AD paradigm in the curriculum system reform}

TAC/TAC-AD is an international agreement for the accreditation of three-year higher engineering education and talents. The signatory countries develop talent accreditation standards based on the agreement. Compared with the previous "Washington Agreement" (4-year school system) and "Dublin Agreement" (2-year school system), the 3-year school system and graduates' quality requirements of TAC/TAC-AD are more in line with the reality of China's higher vocational education.

In recent years, China's higher vocational education has developed greatly in scale, but it has not fully met the social demand for professional talents in quality, reflecting that higher vocational education has a long way to go in professional construction. China's higher vocational education is now faced with the problem of taking a student-centered, result-oriented, professional construction as the starting point of the road to connotative development, which is the only way in the period of "post demonstration" and "post backbone." In this sense, TAC/TAC-AD has a strong reference significance. TAC/TAC-AD does not only put forward the professional standards for certification, but also point out the direction of curriculum construction in higher vocational colleges through the operation of these standards. Learning from its core ideas, analyzing its certification standards, and referring to its development paradigm play important roles in constructing the training specifications of management professionals in higher vocational colleges as 
well as improving the curriculum system reform of management majors in higher vocational colleges.

\section{The curriculum system reform based on the TAC/TAC-AD paradigm}

\subsection{Refining talent training specifications according to talent training objectives}

Talent training specification is the standard of talent training, which includes the kind of talents the school should cultivate and the comprehensive quality requirements that students should meet when they graduate. According to the core concept of TAC/TAC-AD, the talent training process should take the talent training objectives as the starting point, subdivide the training objectives into training specifications, build a curriculum system according to the training specifications, implement curriculum teaching, and finally achieve the training objectives.

Through university-enterprise symposium, business investigation, expert interview, questionnaire survey, and so on in this professional paradigm based on TAC/TAC-AD, the training goal of enterprise digital management talent is refined, decomposed into three dimensions of higher vocational talent training specifications (composite knowledge structure, comprehensive ability structure, and professional quality structure), and coded.

\subsection{Constructing the professional curriculum system according to the talent training specifications}

Based on the paradigm of TAC/TAC-AD, after refining the training specifications, the scientificity and rationality of the curriculum in the current curriculum system should be evaluated according to the training specifications. After the evaluation, the importance of each course in the current curriculum system for the realization of talent training goals and the degree of repetition with related courses is clear; in addition, the missing compound knowledge points, comprehensive ability points, and professional quality points are also evident: first, the indicators of compound knowledge and comprehensive ability are too forward, and the compound knowledge and comprehensive ability related to grass-roots business, grass-roots management, and job migration are obviously insufficient; second, there is a lack of information literacy, social responsibility, and decision-making responsibility in professional quality.

In order to achieve the goal of professional talent training, the traditional discipline system of business management has been broken, the curriculum system reform has been carried out under the guidance of the core concepts and paradigms of TAC/TAC-AD, and the notion of "one main line, combination of two parts, three steps, and four course groups" has been realized.

One main line refers to designing a training scheme with the cultivation of the actual employability of the industry as the main line; combination of two parts refers to building the curriculum system in a way that integrates the industry and education; three steps refer to establishing three steps of ability training, which include grass-roots specialists, middle-level experts, and high-level overall planning; four course groups refer to four major teaching course groups, including basic course group of professional group, general course group of professional group, course group of professional direction, and course group of job migration, to progressively realize the integration of the learner's ability. Each course group is independent of each other and closely connected, forming a strong support for the goal of talent training together.

\subsection{Developing professional curriculum standards according to talent training specifications and curriculum system}

Curriculum standard is a teaching guiding document that stipulates the curriculum nature, curriculum objectives, content objectives, and implementation suggestions of a discipline. In fact, it is what students should know and what they can do after a period of learning. Compared with conventional curriculum standards, the curriculum standards under the guidance of the core concepts and paradigms of TAC/TAC- 
$\mathrm{AD}$ require that in addition to the basic elements of the curriculum, such as the basic concept, curriculum objectives, learning content, learning requirements, and implementation suggestions, all learning contents in each professional curriculum clearly identify the corresponding codes of composite knowledge points, comprehensive ability points, and professional quality points. This can effectively reduce the randomness and subjectivity of teachers in their individual arrangement of teaching contents as well as urge teachers to develop and design courses closely around the talent training objectives, so as to effectively implement the talent training specifications in each course and help students acquire more targeted and market-oriented knowledge, ability, and quality improvement through professional courses.

The logical starting point of curriculum system construction is the educational goal, and the highest level of educational goal is pertaining to the educational concept and school running concept. As one of the important levers in the construction of the school education system, the reform of professional curriculum system in the new business era has pried the reform of professional education mode as a whole and formed personalized professional school running characteristics. Therefore, professional teaching reform should pursue the reform and optimization of the professional curriculum system as well as take-off from the ideal path to be in line with the requirements of the times, the needs of the students, and the pursuit of running a school.

\section{Funding}

This research was supported by the Reform on Curriculum of Management Major Based on TAC/TAC-AD (Sydney Accord) Paradigm - Case Study with Jewelries as Sample by Business Management Major (Project Number: jg20180639) - The First Batch of Research Projects on Teaching Under "13th Five-Year Plan" for Higher Education by Zhejiang Provincial Department of Education in 2018.

\section{Disclosure statement}

The author declares that there is no conflict of interest.

\section{References}

[1] Guan J, Jiang A, 2018, Exploration on Specialty Construction Path of Higher Vocational Colleges Based on "Sydney Agreement". Tourism Today, 000(011): 213.

[2] $\mathrm{Hu}$ J, Xu N, Lu X, 2020, Training Practice of Chemical Professionals Based on "Sydney Agreement". Western China Quality Education, 6(5): 3.

[3] Xiong Y, 2020, Teaching Reform and Practice of Mold Specialty Under Professional Certification. Modern Vocational Education, (52). 